\title{
UDC 544.4;544.47:544.344 \\ MECHANISM OF BIOMIMETIC OXIDATION OF CYCLOHEXANE TO CYCLOHEXANONE BY HYDROGEN PEROXIDE
}

\author{
S.A.Aghamammadova \\ M.Nagiev Institute of Catalysis and Inorganic Chemistry, NAS of Azerbaijan \\ aghamammadova@yahoo.com
}

Received 22.07.2020

Accepted 12.10.2020

\begin{abstract}
The process of gas-phase oxidation of cyclohexane was studied in the presence of a heterogeneous biomimetic catalyst (per-FTPhPFe(III)OH $/ \mathrm{Al}_{2} \mathrm{O}_{3}$ ), at $130-250^{\circ} \mathrm{C}$, in which high yields of cyclohexanone and cyclohexanol were obtained up to $25.2 \%$ with a selectivity of $\sim 80 \%$ at a cyclohexane conversion of $34 \%$. The mechanism of the conversion of cyclohexane to cyclohexanone has been studied in detail, and the coherently synchronized character of the reaction proceeding is shown.
\end{abstract}

Keywords: cyclohexane, oxidation, biomimetic catalysts, cyclohexanone, hydrogen peroxide.

doi:

\section{Introduction}

The oxidation of cyclohexane to cyclohexanol and cyclohexanone is one among the important industrial processes. Both oxidation products are the main industrial precursors of respectively, caprolactam and adipic acid, the building blocks of polymers nylon- 6 and nylon$6,6[1,2]$. In addition, cyclohexanone is in particular also a starting material in the synthesis of insecticides, herbicides and pharmaceuticals [2].

The most promising raw material for the production of cyclohexanol, cyclohexanone and adipic acid is cyclohexane and its derivatives, which are isolated from the gasoline fractions of some oils. During the liquid-phase oxidation of cyclohexane homologues (methyl-, ethyl-, isopropyl-, and dimethylcyclohexanes) with air mixtures of mono- and dibasic acids $\mathrm{C}_{1}-\mathrm{C}_{4}$ are formed. Currently, the main industrial process for the oxidation of naphthenes is the oxidation of cyclohexane to cyclohexanone and adipic acid [3].

The initiation of the oxidation reaction of cyclohexane can be carried out by various methods with application catalysts - soluble salts of metals of variable valence (mainly cobalt salts) and initiating additives (hydrogen bromide, nitrogen dioxide, cyclohexanone), as well as thermally and photochemically [3].

The industrial method for the production of cyclohexanol, cyclohexanone and adipic acid is based on the liquid-phase oxidation of cyclo- hexane with molecular oxygen in the presence of cobalt naphthenate at a temperature of 433$453 \mathrm{~K}$, air pressure of 9-13 atm [4-6]. However, under these industrial conditions, the maximum selectivity of the process does not exceed $70 \%$ at the conversion of cyclohexane up to $9 \%$.

Most of the known oxidation processes of cyclohexane in the presence of various catalysts - MnO, FeZSM, copper pyrophosphate and in the biomimetic iron-porphyrin system $\mathrm{FeP} / \mathrm{O}_{2} / \mathrm{Zn} / \mathrm{AcOH} / \mathrm{CH}_{3} \mathrm{CN}$ are also carried out in the liquid phase [7-9].

The creation of heterogeneous biomimetic catalysts made it possible to carry out some well-known oxidation processes, including the process of oxidation of cyclohexane to cyclohexanol and cyclohexanone in the gas phase, that led to the elimination of the disadvantages existing in liquid-phase oxidation.

Heterogenized biomimetic catalysts based on iron porphyrin complexes have been developed, on which the oxidation processes were carried out in the gas phase. One of the main properties of these catalysts is functional specificity, which is characteristic of enzymes associated with the special properties of protein molecules. The synthesized catalysts mimic the main physicochemical properties of the cytochrome P-450 monooxygenase enzyme, such as activity and selectivity $[10,11]$.

In contrast to the well-known studies on biomimetic oxidation of cyclohexane, carried 
out mainly in the liquid phase, the gas-phase oxidation of cyclohexane on heterogeneous bioimitator, as was shown in $[12,13]$, has significant advantages: the process is carried out in a flow system with a fixed catalyst layer through more simplified technology, where reaction products are not mixed with the catalyst and after the reaction their separation is not required and no additional costs are required.

\section{Experimental part}

The process of monoxidation of cyclohexane was carried out on heterogeneous biomimetic catalysts such as hemin - protoporphyrin iron(III) $\left(\mathrm{PPFe}^{3+} \mathrm{OH} / \mathrm{Al}_{2} \mathrm{O}_{3}\right)$ and perfluorotetraphenylporphyrin iron(III) (per-FTPhPFe ${ }^{3+} \mathrm{OH} / \mathrm{Al}_{2} \mathrm{O}_{3}$ ), which were synthesized in several stages [14]. The primary stage in the synthesis of bioimitators is the dissolution of iron porphyrin complexes in appropriate solvents. Immobilization of active centers on a solid support $\mathrm{Al}_{2} \mathrm{O}_{3}$ was carried out by extracting them from solvents.

Experimental study of the oxidation of cyclohexane on synthesized biomimetic catalysts was carried out in the gas phase in a flowing quartz reactor with reaction zone volume of $3.0 \mathrm{~cm}^{3}$ at the temperature of $130-230^{\circ} \mathrm{C}$ and atmospheric pressure in the presence of biomimetic catalyst with the active part of perfluorinated iron tetraphenylporphyrin backed on a solid $\mathrm{Al}_{2} \mathrm{O}_{3}$ support. As an oxidizing agent were used aqueous solutions of hydrogen peroxide of various concentrations (20-40\%).

Hydrogen peroxide is an affordable and cheap "green oxidizer", according to the principles of the "Green Chemistry" concept and is increasingly used in hydrocarbons oxidation processes $[15,16]$.

Analysis of reaction products was carried out on chromium-mass spectrometer 5975 MSD +7820 GC System and gas-liquid chromatograph 7820A GC System from Agilent Technology and on the chromatograph ЛXМ-80.

\section{Results and discussion}

Experimental studies of the activity of per-FTPhPFe(III)OH/ $/ \mathrm{Al}_{2} \mathrm{O}_{3}$ catalyst deponding on the temperature, concentration of hydrogen peroxide and contact time made it possible to obtain data indicative of its high activity in the process of cyclohexane monooxidation.

Kinetic regularities of cyclohexane conversion over per-FTPhPFe(III)OH/ $\mathrm{Al}_{2} \mathrm{O}_{3}$ biomimetic catalyst as a function of temperature are presented in Figure 1. As shown in figure, oxidation of cyclohexane to cyclohexanol and cyclohexanone at the temperature range of 150 $180^{\circ} \mathrm{C}$ proceeds at the highest rate. With an increase in temperature, the yield of cyclohexene sharply increases and the yield of cyclohexadiene slightly increases, which is explained by the increase of the reaction rate of oxidative dehydrogenation of cyclohexane under these conditions $\left(200-230^{\circ} \mathrm{C}\right)$.

While the yield of cyclohexanol decreases with temperature, the yield of cyclohexanone at $180^{\circ} \mathrm{C}$ reaches its maximum $(10.34 \%)$.

It can be concluded from the nature of the kinetic curves 2 and 3 (Figure 1) that the formation of cyclohexanone probably does not pass through the formation of an intermediate product of cyclohexanol. The temperature dependence of the kinetic curves shows that, starting from $200^{\circ} \mathrm{C}$ $\mathrm{H}_{2} \mathrm{O}_{2}$ decomposition into molecular oxygen stabilizes, that indicates full expenditure of hydrogen peroxide in the system for carrying out of two interrelated reactions. This undoubtedly affects the processes of monooxidation and hydroxylation of cyclohexane. This experimental fact indicates that the processes of monooxidation and hydroxylation are interrelated with the reaction of $\mathrm{H}_{2} \mathrm{O}_{2}$ decomposition and proceed in a coherent manner with it. It is shown in [17] that such reaction system is effectively realized in a coherently synchronized regime. In this context, the kinetic data obtained in Figure1 are consistent with the theory and practice of coherently synchronized reactions [18].

Since cyclohexanone has been the dominant (target) product in our study (from Figure 1$)$, and its maximum yield $(10 \%)$ has been observed at $180^{\circ} \mathrm{C}$, the effect of contact time on the cyclohexane oxidation has been investigated at this temperature.

Kinetic curves in Figure 2 show that the increase in the contact time $(\tau)$ in cyclohexane monooxidation reaction up to 10 seconds the yield of cyclohexanone increases (up to $12.1 \%$ ), and then the yield varies insignificantly. 


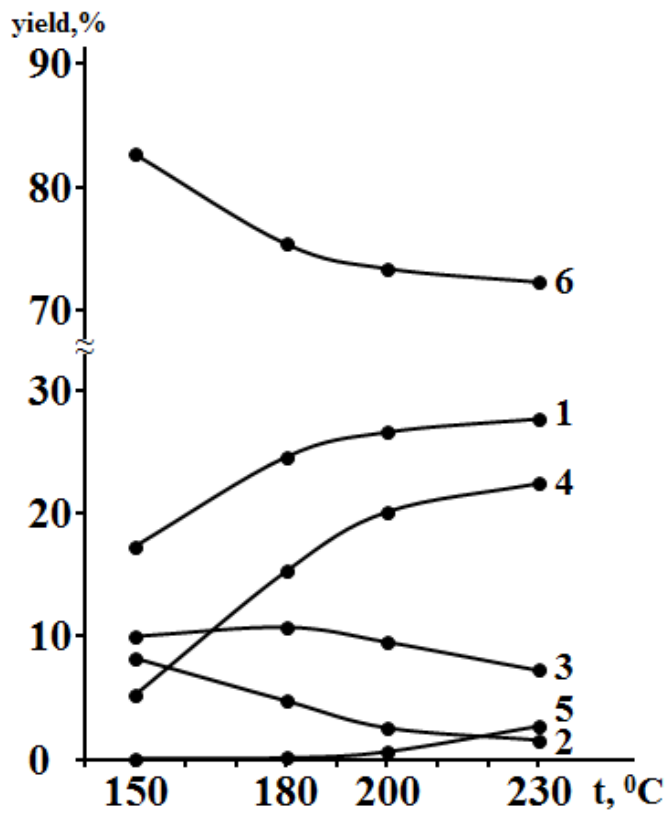

Fig. 1. Temperature dependence of the products yields of cyclohexane oxidative conversion by hydrogen peroxide in a mixture with $6.25 \%$ of $\mathrm{C}_{6} \mathrm{H}_{11} \mathrm{OH}$ and $2.53 \%$ of $\mathrm{CH}_{3} \mathrm{C}_{6} \mathrm{H}_{11}$ on per-FTPhPFe(III)/ $/ \mathrm{Al}_{2} \mathrm{O}_{3}$ biomimetic: $c_{\mathrm{H}_{2} \mathrm{O}_{2}}=25 \%, \quad V_{\mathrm{H}_{2} \mathrm{O}_{2}}=1.41$ $\mathrm{ml} / \mathrm{h}, V_{\mathrm{C}_{6} \mathrm{H}_{12}}=0.9 \mathrm{ml} / \mathrm{h}, \mathrm{C}_{6} \mathrm{H}_{12}: \mathrm{H}_{2} \mathrm{O}_{2}=1: 1.5$. 1 conversion of $\mathrm{C}_{6} \mathrm{H}_{12}, 2$ - cyclohexanol, 3 - cyclohexanone, 4 - cyclohexene, 5 - cyclohexadiene, $6-\mathrm{O}_{2}$.

The rate of cyclohexene production process also increases, while the yield of cyclohexanone increases insignificantly. In this case, conversion of cyclohexane increases with increasing contact time. Kinetic regularities from Figure 2 lead us to the conclusion that cyclohexanone is probably not formed from cyclohexanol. It should be noted that in the absence of cyclohexane, $\mathrm{H}_{2} \mathrm{O}_{2}$ at these contact times has been completely decomposed.

Based on previous studies on coherently synchronized oxidation reactions by hydrogen peroxide $[16,18]$ and the nature of the kinetic curves according too of the experimental results

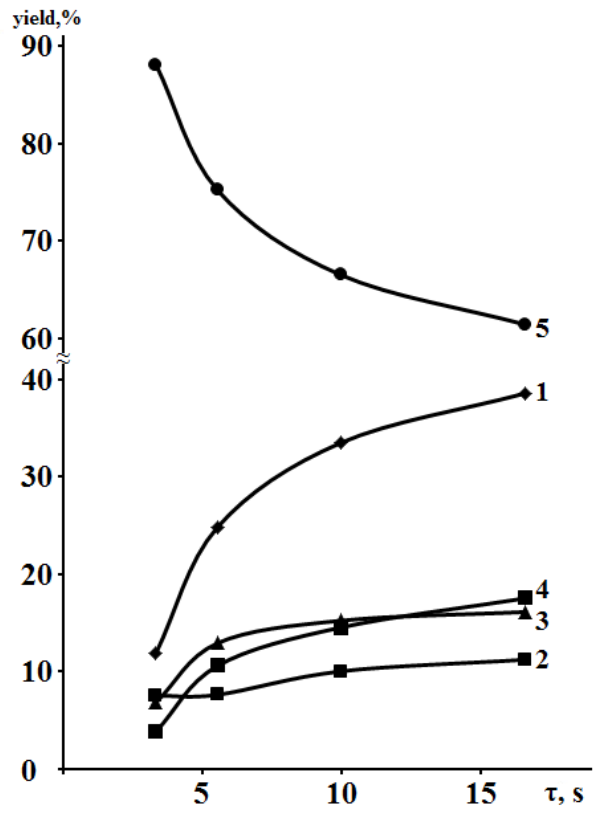

Fig. 2. Dependence of the product yields of cyclohexane oxidation in a mixture with $6.25 \%$ of $\mathrm{C}_{6} \mathrm{H}_{11} \mathrm{OH}$ and $2.53 \%$ of $\mathrm{CH}_{3} \mathrm{C}_{6} \mathrm{H}_{11}$ on perFTPhPFe(III) $/ \mathrm{Al}_{2} \mathrm{O}_{3}$ biomimetic by hydrogen peroxide on contact time: $c_{\mathrm{H}_{2} \mathrm{O}_{2}}=25 \%, t=$ $180^{\circ} \mathrm{C}, \mathrm{C}_{6} \mathrm{H}_{12}: \mathrm{H}_{2} \mathrm{O}_{2}=1: 1.1-$ conversion of $\mathrm{C}_{6} \mathrm{H}_{12}, 2$ - cyclohexanol, 3 - cyclohexanone, 4 cyclohexene, $5-\mathrm{O}_{2}$.

of this process, we can say that the biomimetic oxidation of cyclohexane with hydrogen peroxide is a complex reaction consisting of two coherently synchronized reactions: 1) catalase and 2) monooxygenase. The coherently synchronized nature of the process is associated with the inducing ability of hydrogen peroxide, which contributes to the formation of a highly active intermediate complex, similar to the enzyme-substrate complex. The generalized scheme of coherently synchronized biomimetic oxidation of cyclohexane by hydrogen peroxide is described as follows [10, 16, 18-20]:

Scheme

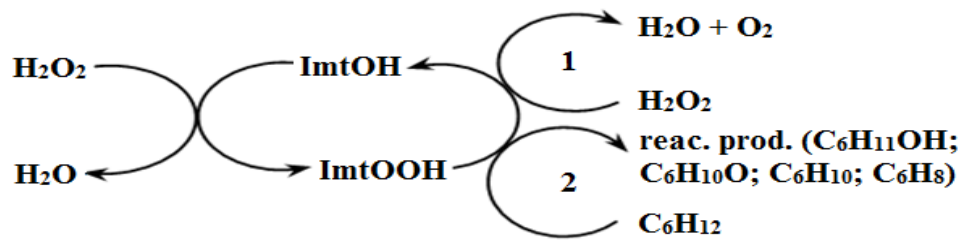


It follows from the scheme that a highly active intermediate ( $\mathrm{ImtOOH})$ obtained as a result of the interaction of hydrogen peroxide with a bioimitator at the first stage of the primary (catalase) reaction, interacts with the second $\mathrm{H}_{2} \mathrm{O}_{2}$ molecule and with cyclohexane in the secondary (monooxygenase) reaction leads to the formation of final reaction products [18 ].

The $\mathrm{Al}_{2} \mathrm{O}_{3}$ we used as a matrix, possessing acid-base properties, has Brensted and Lewis acid and basic centers, which play a key role in the formation of reaction products. Aluminum oxide acts as an electron donor and acceptor, thereby facilitating the cleavage and formation of bonds.

A detailed study of the characteristics of these centers gives a complete understanding of the mechanism of the redox action of a biomimetic catalyst and the possibility of selective transformation of the substrate into target products [21].

Since, according to our experimental data, the peroxidase reaction does not proceed, the probable mechanism of the formation of cyclohexanone from cyclohexane can be presented in the following form according to Scheme I, which shows the electronic mechanism of the catalase reaction with the preparation of the active intermediate complex ImtOOH (1) and the mechanism of its interaction with cyclohexane, which leads to the formation of cyclohexanone on the surface of the biomimetic (2) and (3).

\section{Mechanism of catalase reaction}

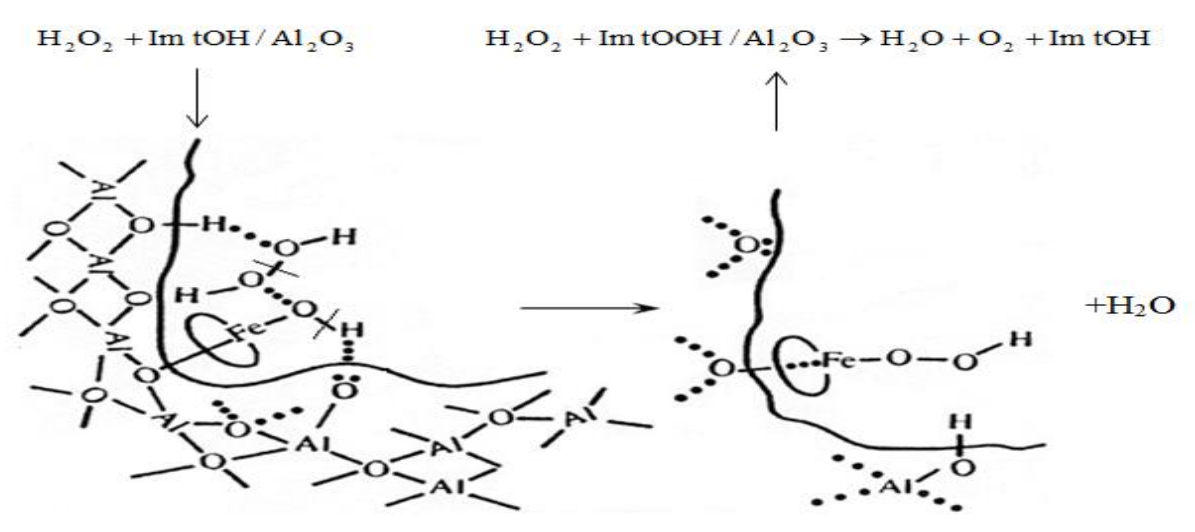

Mechanism offormation of cyclohexanone
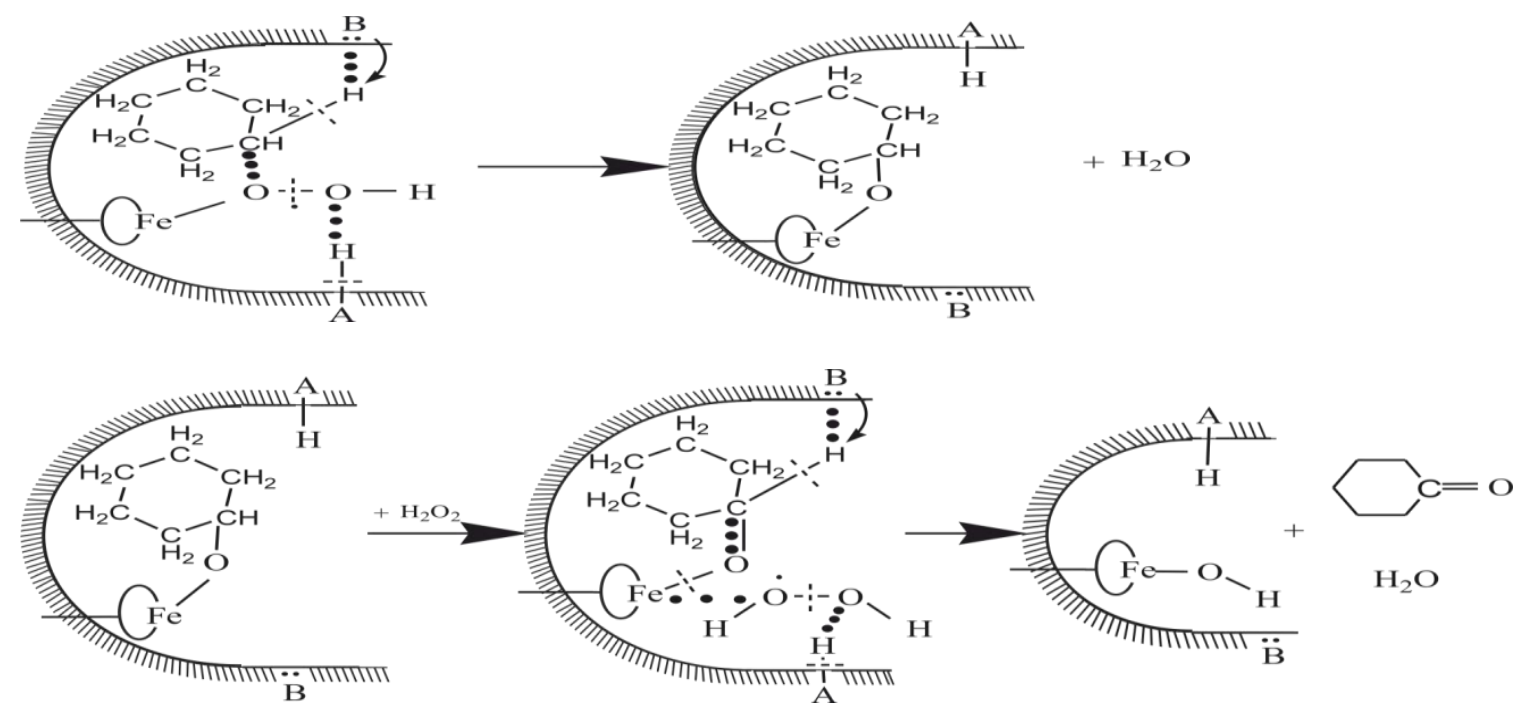
According to the results of studies and the presented schemes (2 and 3), the direct conversion of cyclohexane to cyclohexanone occurs through the formation of an intermediate biomimetic-substrate complex $\mathrm{Imt}-\mathrm{O}-\mathrm{C}_{6} \mathrm{H}_{11}$, which is formed by the interaction of the intermediate $(\mathrm{ImtOOH})$ with cyclohexane (2). The interaction of this complex with another $\mathrm{H}_{2} \mathrm{O}_{2}$ molecule leads to oxidation-reduction transformation of the complex into cyclohexanone, water and original biomimic (3). This mechanism agrees with the fact that cyclohexanone is formed precisely under usage the most concentrated $\mathrm{H}_{2} \mathrm{O}_{2}$ (30\% or more) and a lower temperature $\left(150-180^{\circ} \mathrm{C}\right)$.

\section{References}

1. Gerhard Franz, Roger A. Sheldon, "Oxidation": Ullmann's Encyclopedia of Industrial Chemistry. Weinheim: Wiley-VCH, 2000.

2. Musser M.T., "Cyclohexanol and Cyclohexanone": Ullmann's Encyclopedia of Industrial Chemistry. Weinheim: Wiley-VCH, 2000.

3. Adelson S.V., Vishniakova T.P., Paushkin Ia.M., Tekhnologiia neftehimicheskogo sinteza: Ucheb. dlia vuzov. 2-e izd., pererab. M.: Himiia, 1985. $608 \mathrm{~s}$.

4. Berezin I.V., Denisov E.T., Emanuel N.M., The Oxidation of Cyclohexane. Moscow University Press. English edition Pergamon Press, Oxford. 1966. $304 \mathrm{p}$.

5. Davis J.A., Watson P.L., Grenberg A. Selective Hydrocarbon Oxidation and Functionalization. N.Y.: VCH. 1990. 467 p.

6. George W. Parshall, Steven D. Ittel, Homogenous Catalysis. N.Y.: Willey. 1992. 360 p.

7. Jian-Ying Wang, Feng-Yun Zhao, Run-Jing Liu, Yong-Qi Hu, Oxidation of cyclohexane catalyzed by metal-containing ZSM-5 in ionic liquid. J. Molecular Catalysis A: Chemical. 2008. V. 279. No 2. P. 153-158.

8. Ying Du, Yonglian Xiong, Jing Li, Xiangguang Yang, Selective oxidation of cyclohexane with hydrogen peroxide in the presence of copper pyrophosphate. J. Molecular Catalysis A: Chemical. 2009. V. 298. No 1-2. P. 12-16.

9. Karasevich E.I., Karasevich Iu.K. Mehanizm okisleniia tciclogeksana molekuliarnym kislorodom v biomimeticheskoi zhelezoporfirinovoi sisteme $\mathrm{s}$ donorami protonov $\mathrm{i}$ elektronov. I.
Radikalnyi marshrut. Kinetika i kataliz. 2000. T. 41. No 4. C. 535-542.

10. Nagiev T.M. Himicheskoe sopriazhenie. M.: Nauka, 1989. $216 \mathrm{~s}$.

11. Poltorak O.M., Chukhrai E.C. Fiziko-himicheskie osnovy` fermentativnogo kataliza. Uchebnoe posobie dlia vuzov M.: Vysshaia shkola, 1971. $360 \mathrm{~s}$.

12. Nagiev T., Gasanova L., Mustafaeva Ch., Nagieva I., Abbasova A., Magerramova A., Terner Y. Selective Biomimetic Oxidation of Ethanol by Hydrogen Peroxide on Immobilized Ironporphyrin Catalysts. Russian J. Physical Chem. 2005. V. 79. No 3. P. 382-388. Translated from J. Fiziceskoy ximii. 2005. V. 79. No 3. P. 462-468.

13. Nasirova U.V., Gasanova L.M., Nagiev T.M. The Monooxidation of Ethylene with Hydrogen Peroxide on the per-FTPhPFe ${ }^{3+} \mathrm{OH} / \mathrm{Al}_{2} \mathrm{O}_{3}$ Biomimetic. Russian J. Physical Chem. A. 2010. V. 84. No 6. P. 941-945. Translated from J. Fiziceskoy ximii. 2010. V. 84. No 6. P. 1050-1054.

14. Aghamammadova Sariyya, Nagieva Inara, Gasanova Latifa, Nagiev Tofik. Catalytic monooxidation of cyclohexane by hydrogen peroxide in the gas phas. Reaction Kinetics, Mechanisms and $\mathrm{Ca}$ talysis, April 2019. V. 126. Issue 2. P. 701-715.

15. Aghamammadova S., Nagieva I., Gasanova L., Nagiev T. Coherent-Synchronized Biomimetic Monooxidation of Cyclohexane by Hydrogen Peroxide. Russian J. Physical Chem. A. 2018. V. 92. No 12. P. 2455-2463.

16. Nagiev T.M. Coherent Synchronized Oxidation Reactions by Hydrogen Peroxide. Amsterdam: Elsevier. 2007. 325 p.

17. Aghamammadova S., Nagieva I., Gasanova L., Nagiev T. EUROPACAT 2017. 13th European Congress on Catalysis - A bridge to the future. August 27-31, 2017. Florence, Italy. Book of Abstracts.

18. Nagiev T.M. Vzaimodeistvie sinkhronnykh reaktcii v himii i biologii. Baku: Elm, 2001. $404 \mathrm{~s}$.

19. Nağıyev T.M. The Theory of Coherent Synchronized Reactions: Chemical Interference Logics. Materials Sciences and Application. 2015. V. 6. P. 152-170.

20. Tofiq M. Nağıyev. Sinxron reaksiyalara koherent baxış. Bakı: Şərq-Qərb. 2018. 216 p.

21. Nagiev T.M., Abbasova M.T., Zulfugarova S.Z., Shakhtakhtinskaia A.T., Mamedova Z.M., Termodesorbtcionnoe issledovanie kislotno-osnovnykh harakteristik nanesennykh zhelezoprotoporfirinovykh katalizatorov. Vestn. Mosk. un-ta. Ser. 2. Ximiia. 1997. T. 38. № 1. C. 42-44. 


\section{TSIKLOHEKSANIN TSIKLOHEKSANONA HIDROGEN PEROKSIDLə BİOMIMETIK OKSIDLəŞMəSI MEXANIZMI}

\section{S.Ә.Ă̆aməmmədova}

Heterogen biomimetik katalizator (per-FTPhPFe(III)OH/ $/ \mathrm{Al}_{2} \mathrm{O}_{3}$ ) iştirakında $130-250^{\circ} \mathrm{C}$ temperaturda tsikloheksanın qaz fazada oksidləşməsi prosesi öyrənilmiş, tsikloheksanın 34\% konversiyasında tsikloheksanon və tsikloheksanolun $\sim 80 \%$ selektivliklə 25.2\%-ə qədər yüksək çıxımı müəyyən olunmuşdur. Tsikloheksanın tsikloheksanona çevrilmə mexanizmi dəqiqliklə öyrənilmiş və reaksiyanın koherent-sinxronlaşdırılmış xüsusiyyəti göstərilmişdir.

Açar sözlor: tsikloheksan, oksidlaşmə, biomimetik katalizatorlar, tsikloheksanon, hidrogen peroksid.

\section{МЕХАНИЗМ БИОМИМЕТИЧЕСКОГО ОКИСЛЕНИЯ ЦИКЛОГЕКСАНА В ЦИКЛОГЕКСАНОН ПЕРОКСИДОМ ВОДОРОДА}

\section{С.А.Агамамедова}

Изучен процесс газофазного окисления циклогексана в присутствии гетерогенного биомиметического катализатора (per-FTPhPFe(III)OH/ $\mathrm{Al}_{2} \mathrm{O}_{3}$ ) при $130-250^{\circ} \mathrm{C}$, в котором были получены высокие выхода циклогексанона и циклогексанола до $25.2 \%$ с селективностью $80 \%$ при конверсии циклогексана $34 \%$. Подробно изучен механизм превращения циклогексана в циклогексанон, показан когерентносинхронизированный характер протекания реакции.

Ключевые слова: ичклогексан, окисление, биомиметические катализаторы, ичиклогексанон, пероксид водорода. 